\title{
The challenge of creating a more diverse economics: lessons from the UCR minority pipeline project
}

\section{Gary A. Dymski}

To cite this article: Gary A. Dymski (2017) The challenge of creating a more diverse economics: lessons from the UCR minority pipeline project, Race Ethnicity and Education, 20:3, 385-400, DOI: 10.1080/13613324.2016.1260231

To link to this article: http://dx.doi.org/10.1080/13613324.2016.1260231

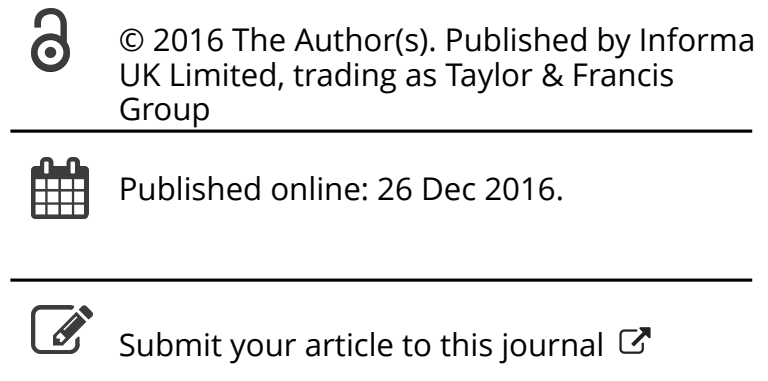

Ш Article views: 119

Q View related articles ๘

View Crossmark data ¿ 


\title{
The challenge of creating a more diverse economics: lessons from the UCR minority pipeline project
}

\author{
Gary A. Dymski \\ Leeds University Business School, University of Leeds, Leeds, UK
}

\begin{abstract}
This paper reflects on the experience of the 1999-2002 minority pipeline program (MPP) at the University of California, Riverside. With support from the American Economic Association, the MPP identified students of color interested in economics, let them explore economic issues affecting minority communities, and encouraged them to consider postgraduate work in economics. The MPP's successes and failures can be traced to the shifting balance in California's racialized political economy, especially a state ballot initiative forbidding the use of applicant race or ethnicity in University of California admission decisions, and to the transformation of economics itself, especially at the level of doctoral training. The MPP experience may be of relevance for other efforts to increase racial/ethnic diversity in social science disciplines.
\end{abstract}

\section{ARTICLE HISTORY}

Received 31 January 2016

Accepted 5 September 2016

\section{KEYWORDS}

Racial and ethnic minority students; pipeline programs; economics; California; proposition 209

\section{Introduction}

This paper reflects on the minority pipeline project (MPP) at the University of California, Riverside (UCR), sponsored by the American Economics Association between 1999 and 2002. The MPP identified students of color interested in engaging with economic issues affecting minority communities, let them research these issues, and encouraged them to pursue doctoral study in economics.

The ensuing discussion of the MPP offers some ideas on how to support minority students' critical engagement with issues of racial/minority inequality in the broader world. It also explores reasons why this program had limited success in its stated aim of increasing the flow of minority students into doctoral study in economics. This relative failure came despite the fact that UCR was able to maintain a racially diverse undergraduate student population, with relatively high levels of success in degree completion among minority

\section{CONTACT Gary A.Dymski g.dymski@leeds.ac.uk}

This paper originated as a presentation at the University of Leeds' 2013 Annual Black History Month Conference, Building the Antiracist University: Next Steps, which was sponsored by the University's Center for Ethnicity and Racism Studies (CERS) on 18 October 2013. The author thanks Dr Shirley Tate, CERS director, for her encouragement of - and patience during - the writing of this text. The reader is forewarned that the author has relied on memory to supplement notes taken during the period examined here. Any errors in this text are solely the author's responsibility. 
students, in the face of mounting political pressures in California and at the federal level to disregard race in university admissions policies. ${ }^{1}$

We proceed as follows. Section 2 summarizes relevant aspects of the history of public policy in California, focusing on the implications of demographic shifts and economic growth for education policy. Section 3 describes the American Economic Association's evolving commitment to insuring racial/ethnic and doctrinal diversity. Section 4 then considers how UCR became a hub for racial/ethnic minority students in the 1990s and 2000s, even as legal challenges ended racial preferences in California's public education system. Section 5 describes the MPP itself. Section 6 concludes and draws tentative lessons from the UCR MPP experience.

Two caveats must be registered at the outset. First, the MPP experiment was undertaken largely without explicit institutional support. Second, the author's research as a heterodox economist focuses on how power, inequality, and uncertainty affect economic processes and outcomes: there is more interest in the historical trajectories and institutional settings of phenomena studied than in the behavioral interplay accompanying them. The emphasis would be reversed for a mainstream economist. The topic covered and they way they are approached - which follow lines of inquiry associated with figures such as Keynes, Marx, and Kalecki - are very different from those in most departments that grant doctoral degrees in economics in the US and UK. ${ }^{2}$ Both these factors certainly shaped both the successes and failures of the MPP.

\section{Growth and race in California: from Brown's master plan to proposition 13}

Seventy years ago, Carey McWilliams described Southern California as an 'island on the land' (McWilliams 1946), due both to its location between mountains and ocean; his phrase also acknowledged the autonomy of California's political and economic trajectory relative to the rest of the nation. Influxes of new settlers in the 1800s, lured first by a gold rush and then by the completion of the transcontinental railroad, pushed aside the state's earlier inhabitants, both Native Americans and Mexicans alike, and built a growth economy geared to continual inflows of speculative capital and empire builders. With the onset of World War II, military bases and military-related manufacturing exploded in scale and size. By the war's end, California accounted for more than half of all US manufacturing capacity (McWilliams 1949); and the US economy as a whole, in turn, accounted for over half of all global manufacturing production. Postwar US programs encouraging home-ownership and creating modern highway systems rechanneled the state's furious growth rate toward suburban expansion. The future seemed without limit for this chronic growth economy. And if the cost of living hovered above that in the rest of the country, its schools were newly built, its teachers wellpaid and newly appointed, and its street and freeway systems glittering and new.

It was widely accepted by the 1950s that this growing residential grid should be accompanied by an expanding public-education system; as Rarick $(2005,137)$ points out, 'Legislators believed, often correctly, that a college campus brought an area not only prestige but also jobs, innovation, and a better-trained workforce.' The rising political trajectory of Governor Pat Brown, who held office from 1958 to 1966, fed the state's hunger for more growth, as well as the expanded supply of water, food, and schools and universities this growth implied. Clark Kerr, taking the reins as University of California President, brokered the creation of a state higher education 'Master Plan', which sought both to maintain academic standards and to 
continually expand access (Douglass 1999; Rarick 2005, 138-139, 147-153). The Plan, which quickly became a foundational reference-point in state political debates, dictated that the University of California have places for the top $12.5 \%$ of California high-school graduates in any given year, while the UC and California State systems together should offer places to the top third. This policy pre-ordained that the Riverside and Davis agricultural experimental stations would be converted into UC campuses, and that new public campuses would be built.

The surge of bond-fueled spending required to undertake the California Water Project and to expand highways and roads, public services, and educational campuses received the necessary legislative support in the early 1960s, the high water-mark of Brown's gubernatorial tenure. By 1966, social conflict and political strife opened the way for Ronald Reagan's successful campaign to replace Brown as California governor. Reagan emphasized law and order, with a double focus: first, to stand tall against Berkeley anti-war protesters; second, to take a hard line on race. The state had, since 1945, confronted the demand by minority advocates for fair employment and fair housing laws. These demands grew more vocal with the passage of the US Civil Rights Act in 1963. In 1964, California passed Proposition 14, opposing discrimination in housing (HoSang 2010, Chapter 3). Ten months later, the Watts race riots exploded the national myth of California as a land of dreamy surfers (Horne 1995). The Delano grape-workers strike, initiated in September 1965 by the United Farm Workers, followed by the March 1968 East Los Angeles walkouts by Chicana/Chicano students in the Los Angeles Unified School District, signaled that Brown Power, like Black Power, was coming of age.

While the bloom was not off the rose of the California myth, racial conflict had become a hardy perennial of state politics. The Vietnam War period pushed the state's military/ ethnic-growth spiral further along. It spurred the rapid growth of military-linked - and heavily Latino - cities such as Oceanside in Southern California and Vallejo and Martinez in Northern California; and it opened the way to the Immigration Act of 1965, which permitted a flood of legal immigration from Southeast and East Asia (initially Korea, the Philippines, Vietnam, and the Asian Chinese diaspora, and eventually China itself), as well as from Mexico and Central America. Further, the economic stress of the combined Wars on Poverty and on Vietnam, combined with growing global competition and 1970s spikes in global oil prices, led to several recessions - 1970, 1974, 1979, 1981 - which marked the end of what has been called the 'Golden Age' of capitalism (in the US and elsewhere in the global North (Glyn et al. 1990).

Combined with the declining pace of migration to California from other states within the United States, these changes combined to shift the terrain of white privilege: it was no longer the case, as in the early 1940s, that minority residents could only reside on the small percentages of California residential land not controlled by racial covenants; now white privilege was protected in property-rich enclaves. However, this barrier was itself eliminated by the California Supreme Court's 1971 and 1976 Serrano vs. Priest decisions. The Court ruled that K-12 education could no longer be funded by property taxes levied by individual school districts, as had previously been the case: the severe disparities in districts' property wealth led to violations of the US Constitution's equal-protection clause.

This decision, together with rising real-estate prices, soon fed a tax-revolt movement. In 1972, the amount of per-pupil property taxes was frozen in response to voter pressure (Kirst 2007). Six years later, a voter-passed Constitutional reform, Proposition 13, rolled back property taxes and 'froze' them at low levels. ${ }^{3}$ Since property taxes were the foundation 
of school finances, this undercut K-12 education. A defining feature of Prop 13 was that when a home was sold, its property-tax burden would be reset in accordance with its higher property value.

The state government stepped in and made up the difference; but the primary financial consequence of Prop 13 was that education finance decisions were made, thereafter, at the state level, and thus were based on the state's general-fund revenues. The same had always been true regarding state support for California's public universities. The general fund itself depended primarily on income taxes. Due to California's progressive tax rates and to the variability of capital-gains income, these revenues were subject to severe boom-bust fluctuations.

Since the state's population was rapidly becoming more heavily minority - due to the impact of immigration from Asia and Latin America, in particular, and of differential birth rates for different demographic groups - a perpetual conflict was embedded in state politics: aging, largely white homeowners without school-age children, interested in low tax rates and law-and-order, vs. a younger, largely minority population with school-age children. Prop 13 had another key provision: it required a two-thirds vote of the California legislature to pass a budget and to pass a state tax increase. So state tax rates and local property-tax rates were both effectively locked in, as Prop 13 became a 'third rail' issue in California politics. Thus, in good fiscal years, spending might increase; in bad years, it tightened.

The result of these racially inflected, homeowner-newcomer conflicts in state finance was a systematic erosion in the fiscal resources available to public schools. While California had the 11th highest level of per-student K-12 expenditures among the 50 states in 1959-1960, its rank fell to 16th in 1969-1970, 22nd in 1979-1980, 32nd in 1989-1990, and 37th in 19992000. ${ }^{4}$ After the subprime crisis, which hit California disproportionately hard, California's 2010-2011 per-pupil K-12 expenditures fell to 50th; only Utah spent less. ${ }^{5}$

This steady fiscal pressure on schools and educational resources had consequences. Parents who could afford to live in more expensive (and typically more white) communities with good public school systems moved there; private schools also proliferated. While the public University of California system retained its prestige, the affirmative action policies that had insured ethnically mixed entering classes were increasingly challenged. Most famously, the US Supreme Court ruled, in its 1978 Board of Regents vs. Bakke decision, that while race could be considered as one consideration in admission decisions, racial quotas were impermissible.

\section{Diversity and American academic economics}

The economic and social macrodynamics that led California from postwar building phase to tax revolt in less than two decades has had similarly dramatic effects on the academic economics profession. The diversity of theoretical perspectives in academic economics was profoundly affected, as was the representation of racial/ethnic minorities within the profession.

From the mid-1960s to the mid-1970s, significant space was provided in mainstream journals for dialogs between economists holding 'mainstream' views and those expositing heterodox approaches rooted in the ideas of Marx and Keynes. An extended controversy over the treatment of production in aggregate models, featuring mainstream proponents disproportionately based in Cambridge, Massachusetts, and heterodox economists linked 
to Cambridge, England, raged for a decade (Harcourt 1969). This 'Cambridge controversy over capital' was not an isolated case: for example, Crotty and Rapping (1975) published a no-holds-barred left critique of the federal budget in the flagship American Economic Review in the mid-1970s; and Harrison (1972, 1974a, 1974b) published a series of papers on the ghetto economy (that is, the economic dynamics of the segregated inner-city economy) in top-ranked mainstream journals.

However, this window of academic exchange for heterodox economists in mainstream journals soon closed. The steady growth and low inflation of the 1950s and 1960s was replaced by stagnation and crisis. This legitimized orthodox articles demonstrating that 'Keynesian consensus' macroeconomic models led to misguided over-reliance on state policies; liberating market forces and corralling the state was needed to renew growth. Any interest that more tolerant mainstream economists had had in dialogs with Keynesian and neo-Marxian models challenging the premises of equilibrium-based economics largely evaporated. After the late 1970s, analyses of 'real world' developments from a Keynesian/ Marxian perspective that did not prioritize mathematical modeling or econometric results could be published, in the main, only in heterodox journals.

Meanwhile, the inattention of the economics profession to issues affecting minorities drew a response. In 1969, Robert S. Browne founded the Black Economic Research Center in Harlem; its advisors and staff undertook policy-oriented research focused on reparations and Black economic development, among other issues. In that same year, the Caucus of Black Economists was founded, and the Review of Black Political Economy (RBPE) was launched, edited by Dr Browne. His founding statement envisioned the RBPE as 'an hospitable arena in which black people could explore ideas as to how they might bring about effective and substantial improvement in their collective economic position' (Betsey 2008, 36).

In the following year, the Caucus of Black Economists initiated discussions with the American Economic Association executive board about the paucity of minority economists (Collins 2000). ${ }^{6}$ This led to the founding in 1974 of the Committee on the Status of Minorities in the Economics Profession (CSMEP). Its goal was to increase the representation of minorities among academic economists, with the twin purposes of improving economists' policy advice and providing more role models for young minority students. As Collins (2000) documents, the percentage of (US national) minority students receiving bachelors' degrees is below that for white students, and the percentage of minorities receiving doctorates is half of this low level (and has remained there from the 1970s to the 1990s); and the representation of minorities in academic positions is a third of that low level (about 1-2\% of the total, for US-national faculty members).

That same year, CSMEP launched the first annual Summer Program, with the aim of preparing aspiring minorities for doctoral study in economics. By 1998, the CSMEP's Summer Program had hosted 634 students. Collins (2000) found data for 348 of these students. Of this total, 129 had started a PhD program; 46 had completed their doctorates; 56 were currently enrolled, and 27 had left without earning a doctorate. To put these figures into context, the 3990 faculty members in US academic economics departments as of 1998 included only 150 Black and Hispanic members (Collins 2000, Table 7). 


\section{Riverside: after the end of affirmative action, the rise of a racially diverse campus}

Since its conversion from an agricultural demonstration station in 1954, the Riverside campus of the University of California has held a distinctive place within the system. Riverside was originally envisioned as an experiment - a small liberal arts college inside the UC system, a 'Swarthmore of the West' (Agha 2004). This experiment soon gave way to pressures stemming from population growth, which triggered University expansion under the Master Plan. To relieve pressure on the Berkeley and Los Angeles campuses, Davis and Riverside were converted into general campuses, and several new UC campuses - Santa Cruz, Santa Barbara, Irvine, and San Diego - were built in attractive seaside locations. UCR struggled, as its smoggy inland site made it the least attractive general campus option for UC-eligible students.

\subsection{An end to affirmative action}

Proposition 13 became law in California in the June primary election of 1978. While Democratic Governor Jerry Brown (son of Governor Pat Brown) was re-elected in November 1978, his colorful personal life and his political agenda - including advocacy of environmental sustainability and of the creation of a state space agency - were out of step with a political shift toward 'traditional values' and nationalism. The national re-alignment, marked by the 1980 Presidential victory of former California governor Ronald Reagan, was followed in California by 1982 and 1986 election mandates for pro-business Republican Governor George Deukmajian. In 1990, the Republican mayor of San Diego, Pete Wilson, was elected California governor on the strength of a law-and-order agenda that included the rollback of programs benefiting minorities and undocumented immigrants. Wilson appointed Ward Conerly to the Board of Regents of the University of California in 1993. Conerly, a politically connected small-business owner whose firm had taken advantage of governmental affirmative-action programs over the years, was an outspoken opponent of affirmative action programs (Musgrove 1999).

Wilson's successful 1994 re-election campaign featured his support for Proposition 187, which prohibited undocumented immigrants' access to health, education, and social services. ${ }^{7}$ In 1995 Conerly won Regental support for ending affirmative action in the University of California. Governor Wilson, seeking to bolster his bid for the 1996 Republican Presidential nomination, supported Proposition 209. This California referendum sought to ban the use of race, sex, ethnicity or national origin - that is, affirmative action - in the provision of public services. Ward Conerly campaigned fiercely for the measure. It passed 54-46 in November 1996, at least in part because many Californians voting for the California Civil Rights Initiative mistakenly thought their 'yes' votes registered support for, not opposition to, affirmative action (Musgrove 1999).

These broader political trends deeply affected public higher education generally, and the UC system and UCR in particular. The Bakke decision effectively opened the floodgates for further legal attacks on affirmative action programs aimed at reducing racial disparities in university admissions (Solórzano and Yosso 2002). Ethnic studies programs across the country, targeted by well-funded campaigns (Nicol 2013), were eliminated or consolidated. At UCR, what had been several distinct departments (Black Studies, Chicano Studies, and 
Native American Studies) were merged into one 'ethnic studies' department in 1981. The Regents' 1995 anti-affirmative action resolution and the Proposition 209 campaign, publicly led by a UC Regent and supported by private donors, was broadly resisted by UC faculty and students (Taylor 1999). The implementation of Proposition 209, once it was passed, had a devastating effect on the number of minorities admitted to UC law and medical schools (Karabel 1999; Moran 2000).

\subsection{The 'tidal wave' comes to UC riverside}

A collision between the political mandate to end affirmative action, the tax revolt, and the demographic bargain built into the Master Plan was inevitable. Popular and political support was mobilized to insure that the 'tidal waves' of prospective higher education students entering the system from the early 1990s onward - the children of the US 'baby-boomer' generation and of immigrant households - would find places in the state's public universities. ${ }^{8}$ Sustaining this bargain even as Prop 209 bit home meant raising enrollment fees; for the UC system specifically, it also meant finding campuses with growth capacity. Riverside volunteered itself for this expansion.

The Riverside campus had languished in its post-'Swarthmore of the west' period; rumors circulated that it was targeted for closure. Embracing 'Tidal Wave' growth insured survival. The campus's location 55 miles to the east of downtown Los Angeles put it near the center of population growth in Southern California - both the African-American and Chicano-Latino hubs of South Central and East Los Angeles, and the rapidly expanding Asian-American 'ethnoburbs' (Li 2008) of the San Gabriel Valley. Consequently, Riverside met its Master Plan commitments by drawing heavily on this largely minority and immigrant population base. Given the complex family demands on minority/immigrant students, their families' lower-than-average incomes, and rising UC tuition, most of UCR's growth came from minority commuter students.

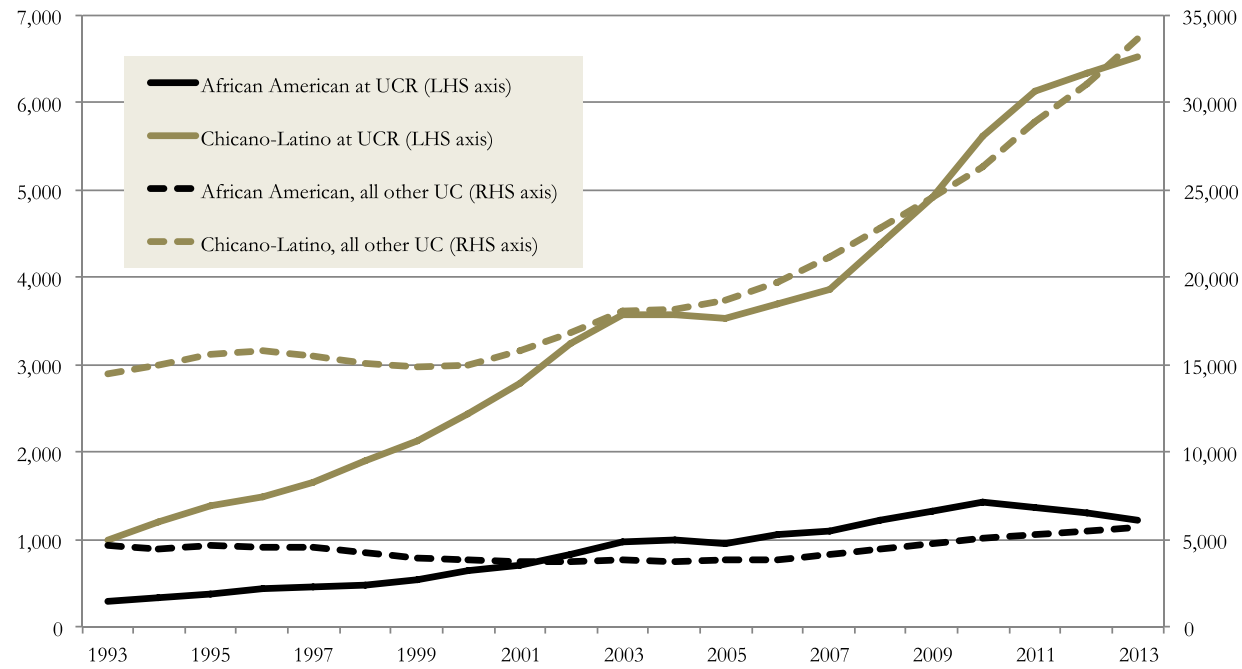

Figure 1. African-American and Chicano-Latino undergraduates enrolled, UC Riverside vs. other UC campuses, 1993-2013. 
Figures 1-4 depict various aspects of UC undergraduate enrollment growth between Fall 1993 and Fall 2013. Figure 1 contrasts the rising numbers of African-American and Chicano-Latino students at UCR with those at the other UC campuses. ${ }^{9}$ Whereas the number of African-American students in other UC campus declines by $18 \%$ between 1993 and 2004, it increased by $240 \%$ at UCR; the changes in Chicano-Latino enrollments are, respectively, increases of 25 and 259\%. Figure 2 shows Asian-American enrollments rising rapidly, both at UCR and at other UC campuses (the respective percentage increases for the 1993-2004 period are 53 and 151\%). This figure also illustrates that white student enrollments remained relatively constant (0.3 and 3.4\% between 1993 and 2004, respectively).

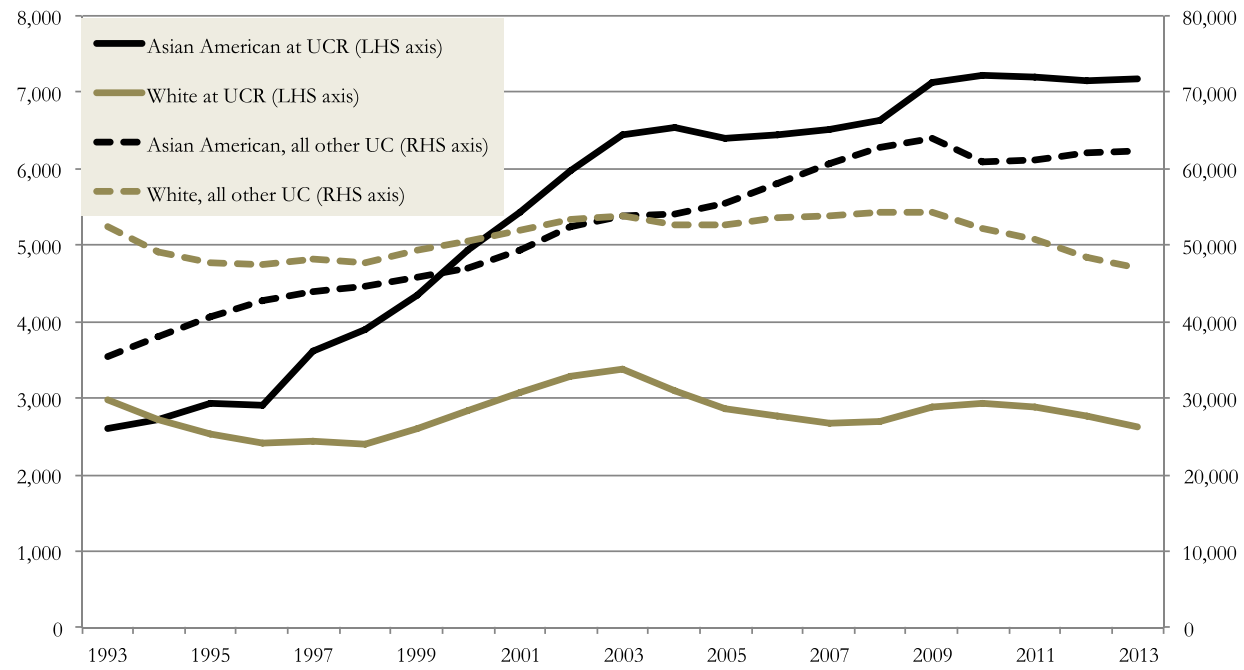

Figure 2. Asian-American and White undergraduates enrolled, UC Riverside vs. other UC campuses, 1993-2013.

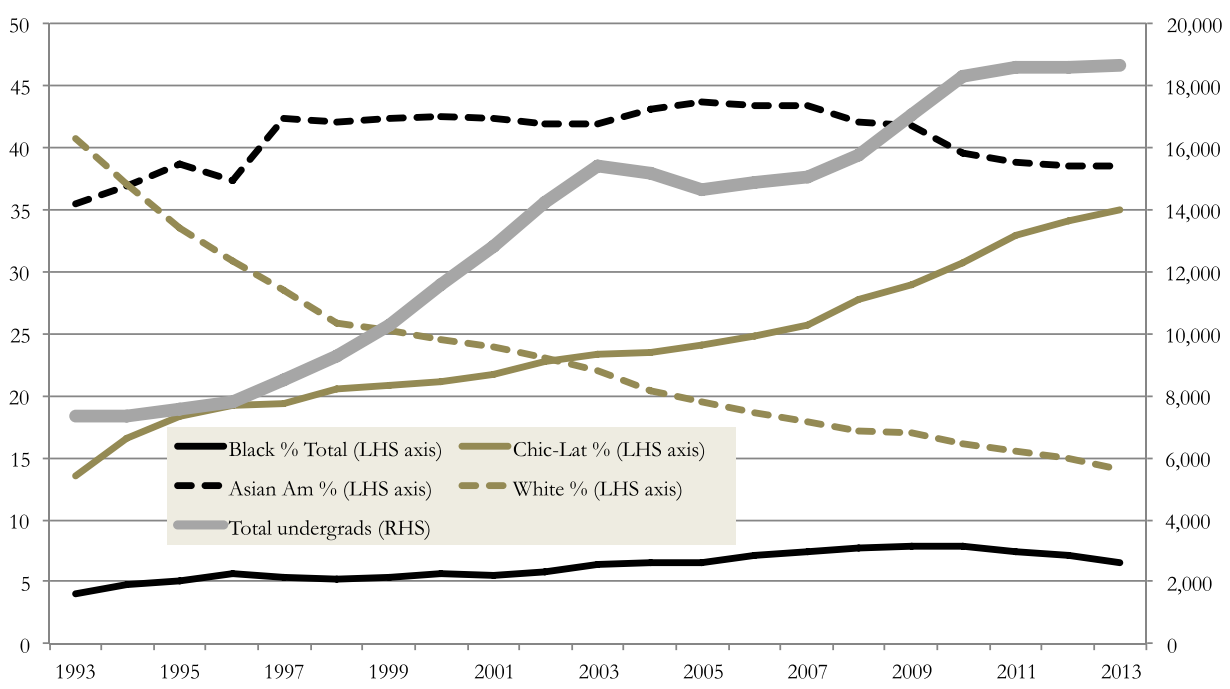

Figure 3. Undergraduate enrollment percentages by ethnicity plus enrollment total, UC Riverside, 19932013. 


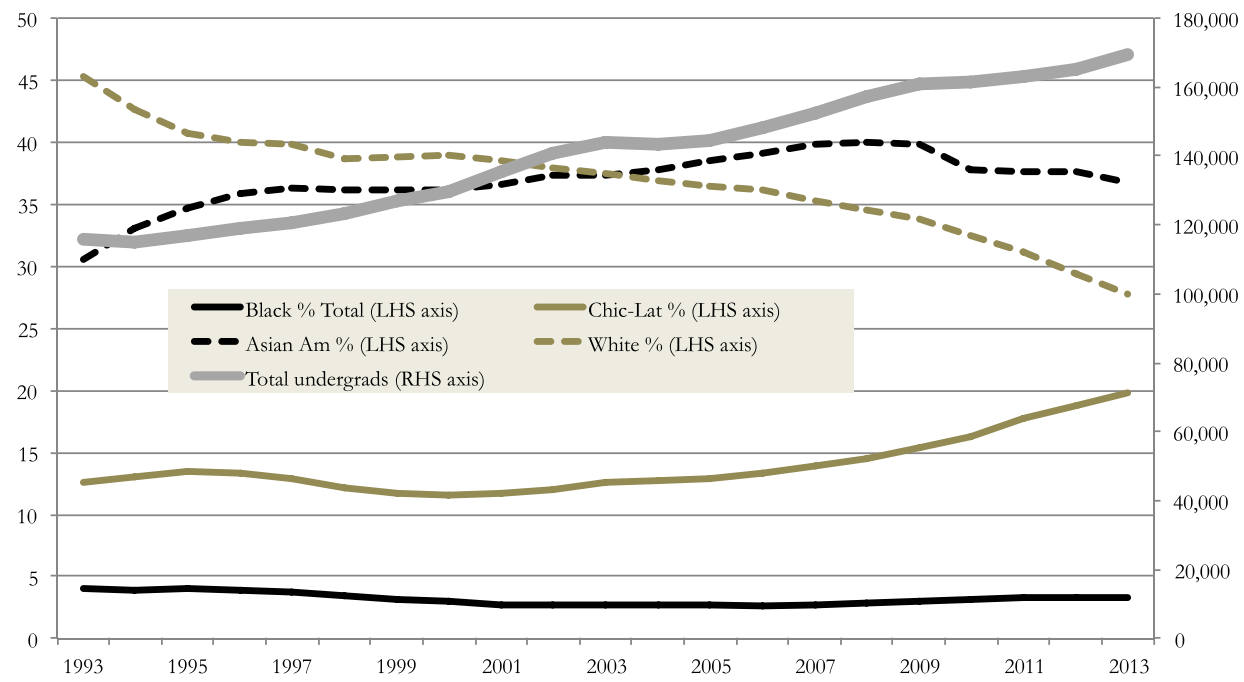

Figure 4. Undergraduate enrollment percentages by ethnicity plus enrollment total, all UC campuses except Riverside, 1993-2013.

Note that while the UCR/Other-UC data are depicted at a scale of 1:5 in Figure 1, they are shown at a scale of 1:10 in Figure 2. This demonstrates the 'minority-focused' nature of Riverside's campus. Figures 3 and 4 contrast the rapid rising percentages of minority students (and declining share of white students) at UCR with the more moderate trends at other UC campuses; these figures also depict overall enrollments.

Thus, despite the legal restrictions imposed on the UC system's ability to recruit for ethnic/racial diversity, its undergraduate population became more ethnically diverse. This was especially so for UCR, which was among the 'non-selective' campuses in the system. ${ }^{10}$ In the 2001 U.S. News and World Report computations, UCR ranked as the third most ethnically and racially diverse public university in the U.S. The expected implication of taking on a heavily minority student body with a family income $\$ 10,000$ less than for other UC campuses is that Riverside would be the least among equals. One would further anticipate that campus morale might plunge and student drop-out and time-to-degree rates might climb.

UCR did not, however, slink down this path. Keyed by the 1992 arrival from UCLA of UCR chancellor Raymond Orbach, it embraced its future as a multi-cultural, multi-ethnic institution. Chancellor Orbach made two immediate moves: he raised performance standards for UCR faculty and personally led an aggressive, all-out recruiting drive in the predominantly minority, lower income, heavily immigrant high schools of the eastern portions of Los Angeles. If these schools would institute more demanding curricula that complied with UC admissions standards, their 'best and brightest' students could apply to UCR. Second, UCR maintained and continued to invest in its distinct student-support and activities centers; there are distinct academic/social hubs for African-American, Latino/Chicano, Asian-American/Pacific Islander, Native American, and international students, each run by a full-time director assisted by a small staff. Providing distinct 'homes' permits student leaders and student-services staff to utilize culturally nuanced encouragement to students, providing social and emotional validation and helping facilitate successful competition in the academic sphere. The result is that minority students in a diverse multi-cultural context 
are made to feel welcome on campus. Informal evidence collected by UCR admissions counselors indicates that this ethnic mix and the campus's reputation as being supportive of minority-student presence has helped make Riverside a destination campus for many minority applicants to the UC system. ${ }^{11}$

\section{The minority pipeline program at UCR}

Just as UCR enrollments entered a period of precipitous growth, I left my former academic position at the University of Southern California (USC) and joined the economics faculty at UC Riverside. In my five years at USC, I had compiled a list of publications, as the 'publish or perish' system demands. These were all, however, in heterodox economics journals or journals outside of economics; as such, they would not suffice for a successful tenure application to USC's ambitious mainstream economics department; UCR's economics department, on the other hand, had become a national beacon for heterodox economics.

In 1990 and 1991, some collaborators and I had undertaken an extensive report for LA Mayor Tom Bradley and the City Council on racial and income inequality and banking in the city. The report was released in early November 1991. Just under six months later, the city burned. From 29 April to 4 May 1992, the LA uprising - triggered by judicial inaction in response to the taped beating of Rodney King - devastated parts of the city. ${ }^{12}$ Many public forums were held in subsequent weeks throughout the city; as one result of such events, scholars such as Eugene Grigsby, Melvin Oliver, and Paul Ong made major advances in linking economic dynamics, racial inequality, and urban social movements.

All these events created a sense of urgency about racial/ethnic inequality in Southern California, then, just as the UC student 'Tidal Wave' landed at UCR. In Fall 1994 and Fall 1995, I offered an undergraduate module called 'The Political Economy of Los Angeles.' I also sponsored four students in summer 1994 under the auspices of the UCR-funded Minority Summer Research Internship Project (MSRIP). Two of these modules' students went to the CSMEP Summer Program - and one of those two, a Chicano/Latino student, went on to receive a doctorate in economics from Duke University. ${ }^{13}$ While offering this summer program, I made contact with Professor Cecilia Conrad of Pomona College. Cecilia, a CSMEP board member (and now editor of the RBPE), wanted to support some experiments in building the pipeline of minority economics students.

We agreed on trying one such program at UCR, due to its growing diversity (Figures 1-4), its reputation for supporting minority students' success, and the fact that UCR had sent students on to both the CSMEP Summer Program and even graduate study in economics. The premise of the experiment was that many students who might otherwise gravitate toward economics were discouraged by the formalism and abstract content of introductory modules. ${ }^{14}$ Why not, then, contact students in creative ways at formative stages in their undergraduate careers?

The UCR MPP's first year of operation was 1999-2000. Presentations about the MPP were made in open meetings held at each of the four minority-student activities centers, in the economics department, and at the UCR honors program. A speaker series was initiated, as were study groups and some innovative methods of academic staff/student contact:

1. In four different programs, invited speakers spoke about their own life experiences in economics in interactive sessions, presented formal seminars, and then met informally with students and faculty. These guests included two Latino economists 
(Ron Oaxaca from University of Arizona and Arturo Gonzalez from Arizona State University), an African-American economist (Curtis Haynes from Buffalo State University), and an Asian-American economist (Paul Ong from UCLA). These visits, co-sponsored by the minority student program centers, received enthusiastic support from these centers' staffs and students.

2. Economics study groups were initiated for a course in intermediate macroeconomics taught in Spring 2000 (Conrad and Sharpe 1996; Karabel 1999; Moran 2000). While aimed at minority students, these groups were open to all participants. They enabled participating students to improve their worksheet and exam performance. Further, the UCR Learning Center trained special peer-group course counselors; these counselors' expenses were funded by the MPP.

3. An experimental approach to faculty-student contact was tried out for the Spring 2000 intermediate macroeconomics course mentioned above. After the 225-student Tuesday-Thursday lecture concluded, anywhere from 3 to 35 interested students convened at patio tables in the UCR Commons area for informal two-hour sessions. Topics ranged from module concepts to mentoring to discussion of professional experience. While all students were welcomed at these sessions, the MPP was advertised. Minority students were disproportionately represented at these sessions. Among the attendees were two members of UCR's varsity basketball team. ${ }^{15}$

In the second year of implementation, academic year 2000-2001, these activities were sustained. ${ }^{16}$ In particular, item 2 was augmented. Learning Center staff institutionalized peer-counseling study groups for microeconomics and macroeconomics. These counselor and study-group sessions for economics modules were subsequently built into the Learning Center's operating budget. ${ }^{17}$ In addition to the activities named above, three more were added: two innovative undergraduate courses open to non-majors; a distinguished guestscholar visit to UCR, sponsored by the MPP; and a summer research initiative.

The innovative course offerings in 2001 and beyond included the re-launching of Economics 146, Urban Economics. Like the Honors module, Economics 146 took a hands on' approach. In 2001, for example, most students participated in a community-based project in conjunction with the UCR-affiliated Community Digital Initiative (CDI) at the Cesar Chavez Center. The class undertook a multi-dimensional study of the CDI's IT training program for at-risk youth, which had the aim of placing these youth in local firms. Economics 146 students met with participating youth, interacted with staff, assessed local secondary and post-secondary IT-training programs, and conducted surveys of both IT-related and non-IT small businesses. The study reached a pessimistic conclusion - there was little evidence of a latent or real demand for these IT-trained youth's labor. The project did succeed in interesting some Economics 146 students in the challenges of urban economic development.

In that same academic year, the UCR Honors Program agreed to sponsor an honors module on racial inequality. This Winter 2001 module, aimed at non-majors with no background in economics, was opened to UCR students beyond those in the Honors program. Approximately 24 students, disproportionately minority, enrolled in this course in each of the three successive years in which it was offered. Module students implemented hands on' tests of the presence of racial inequality in the market economy.

During May 2001, James Stewart, a professor and former vice provost for educational equity at Pennsylvania State University, spent a week at UCR as a scholar in residence. 
Professor Stewart, formerly editor of the RBPE and President of the National Economics Association was, in that period, president of the Association for Black Studies. He had numerous meetings with university executives, economics and academic staff, and students. He gave lectures and presentations for the student Economics Honors society, California State University, San Bernardino (CSUSB), Economics 146, and the African Student Alliance. His visit galvanized many students' interest in economic issues affecting minority communities.

The final event in the 2000-2001 academic year was a summer research project. Minority students identified through MPP events were invited to participate in a special summer research initiative. With support from the MSRIP program, this initiative provided a firsthand research experience permitting undergraduates to connect economics concepts with the circumstances of communities like those in which they had grown up. Seven students were selected for participation via a screening process: three through the MSRIP, and four through the resources of the MPP. These students included four African-Americans, one student whose parents are African-American and Native American, one Asian-American, and one international Asian student. In addition, six students participated on a volunteer basis: one Latino student, one African-American student, and four Asian-Americans. Helping in the coordination of this project was Professor Carolyn Aldana of CSUSB, a Latina, who had earned her doctorate in economics from UCR in 1995.

This lively and motivated cohort of students took a large share of responsibility for designing and implementing their research project. They assessed the access of minority-owned small businesses in the City of Riverside and in a portion of the eastern San Gabrial Valley to customers, to suppliers, and to credit. The project unfolded over 8 weeks during summer 2001. The students succeeded in obtaining 168 completed surveys, providing the basis for a co-authored paper, which was completed in the Fall 2002 quarter. While the MPP ran for a third year, we turn now to an assessment.

\section{Conclusion: an assessment of the UCR MPP}

The MPP posed a question: can classroom and non-classroom methods be used to motivate minority students to consider doctoral study in economics? The answer is unambiguously yes. It also increased many students' proficiency in economics, and underwrote several collectively planned and implemented research projects. Several MPP participants went into the CSMEP Summer Program. One MPP participant became the first male AfricanAmerican valedictorian at a UCR graduation (see footnote 15).

But did the MPP succeed in producing more economists? No. One participant from the three years received a degree in agricultural economics; another received a doctorate in public policy (and is now a professor in the public New York university system). Why not? One reason is that many participants in the MPP had heavy family obligations, including the provision of financial support, which blocked any thought of doctoral study. Other participants came from families without university experience and with ideas about their sons' or daughters' future trajectories which did not include graduate study.

Two MPP members were accepted into economics doctoral programs, and spent a year or more therein. However, they did not stay on; others did not try this path at all. Undoubtedly, the heavily formalistic and mathematical training of US economics doctoral training constituted a double barrier: first, all the MPP participants had graduated from California public 
schools, whose systematic defunding has been documented above; second, the community-focused work that the MPP students undertook is little valued in economics doctoral training. In effect, the very work that had led students to consider economics would push them away once they got there.

Another factor in the MPP's failure to generate more economics doctorates has to be laid to the guidance provided. First, the author did not succeed in recruiting colleagues to join in this program, both because no financial incentives were available, and these colleagues generally had no experience in community-based work. Second, the author's own research interest imposed limits. The topics highlighted in MPP activities and modules stood at some distance from that of mainstream economics - which is what one encounters in required doctoral coursework. In effect, MPP students were being pulled toward perspectives more common in sociology or geography than in economics graduate programs. Table 6 in Collins (2000) sets out the academic fields in which minority and non-minority economists work: political economy, one of the author's fields, is not even listed as a topic; and urban/regional economics encompasses a total of only nine minority economists nationwide.

Academic studies published after the termination of the MPP suggest that encouraging student interested in the economic aspects of the communities like those they had grown up is not a common pathway into the profession. Stock and Siegfried (2015) document that since 1982, foreign and not domestic students have received the majority of economics PhDs from US universities (currently, the figure stands at 55\%). And Evans, Grimes, and Becker (2012), in an examination of what led eminent economists to enter the field, find that few were engaged with economics as undergraduates.

But this underlines, rather than undercutting, the importance of linking research in economics to the economic and social dynamics that affect minority communities. The point of training community-minded students as economists is to ensure that work which renders the structure of racial inequality visible is done within the domain of economics, rather than being possible only outside of it. The importance of this cannot be exaggerated, at a time when the public policy trend toward invisibilizing white privilege in color-blindness continues (as the passage of the 'No Child Left Behind' Act of 2001 illustrates (Leonardo 2007)).

That having informed participants - those who have experienced urban inequality in the US, for example - at the analytical table matters is evident by registering the change in focus in economists' writing about credit and race in a short space of time. In the 1990s, Munnell et al. (1996), economists in the Federal Reserve system, produced evidence demonstrating the existence of racial redlining in Boston, in a series of path-breaking papers. This work, in effect, critiqued the structure of racial inequality. But when four Federal Reserve economists wrote a definitive study of the causes of the subprime crisis (Gerardi et al. 2008), they focused primarily on the existence of neighborhood spillover effects in housing prices - the structure of racial inequality was off their radar. Even while subprime loans were being introduced into the marketplace, two different papers used very similar analytical frameworks based on asymmetric information in a principal-agent setting to come to very different conclusions: Calomiris, Kahn, and Longhofer (1994) argue that credit-market redlining is a legitimate practice because those who are redlined, if they were not to be redlined, would default at higher rates; and Dymski (1995), who condemns this practice as unjust on its face. This inattention to the socio-economic dynamic of race encourages work about economic issues imbued with racial dynamics which pushes race even further into the background; as an example, consider the paper by Ambrose, Capone, and Deng (2001) 
which considers mortgage foreclosures as 'put options' for homeowners. It comes as no surprise to see Calomiris and Haber (2015) subsequently blame government interference in market processes for the subprime crisis.

There is something broken about a profession whose most respected experts almost invariably blame government interference for economic policy failures and crises, with the consequence that government policy-makers have even less scope for halting the chaos that can result when market forces are freed of any constraint. It cannot be too much to hope that those within the discipline can remake it as a tool for taking on, rather than invisibilizing, the social divisions that stand in the way of a more widespread prosperity.

\section{Notes}

1. The expression ' $\mathrm{K}-12$ ' denotes 'Kindergarten to 12 th grade' - that is, the entirety of 'grade school,' 'middle school,' and 'high school' in the US system. Students completing grade 12 can either terminate their schooling, enter vocational programs, or enroll in a university.

2. Dymski (2014) compares heterodox and mainstream approaches to economics.

3. Since 1911, California has had an initiative procedure wherein proposed changes to the state's constitutions can be considered as ballot propositions in general elections. Passage requires only a simple majority of all those voting. This Populist Era mechanism, originally passed to empower grassroots sentiment, now regularly attracts millions of dollars from the 'third house' (Michael and Walters 2002).

4. The source of these statistics is Table 194 in the Digest of Educational Statistics, 2010, US Department of Education. Washington, DC, 2010. See https://nces.ed.gov/programs/digest/ d10/tables/dt10_194.asp

5. See John Fensterwald, 'Latest - but outdated - Ed Week survey ranks California 50th in per pupil spending,' EdSource, January 13, 2014. Accessed at http://edsource.org/2014/latest-butoutdated-ed-week-survey-ranks-california-50th-in-per-pupil-spending/56196.

6. As Collins notes, 'minority' was defined to include Blacks, Hispanics, and Native Americans.

7. Proposition 187 was ruled unconstitutional by a federal appellate court in 1987; Democratic Governor Gray Davis chose not to appeal the ruling, and the measure was never implemented.

8. See California Citizens Commission on Higher Education (1999), Bracco and Callan (2002), and http://www.ucop.edu/acadinit/mastplan/.

9. Native American students are excluded from Figures 1-4 due to their small numbers (as are international students and students not specifying their ethnicity). Note that the enrollment of Native American students at UCR increased 44\% between 1993 and 2004, while at other UC campuses it fell by $27 \%$.

10. Students meeting the 'Master Plan' threshold were assured of a place in the UC system, but not at the campus of their choice. So while some campuses could select from among a surplus of applicants, other campuses would take students who were UC-qualified but whom other campuses had not accepted.

11. Ball, Reay, and David (2002) provide empirical evidence that campus ethnic mix affects minority students' choices among higher education institutions. UCR's strength in attracting and retaining students of color has led to its being ranked first in 2014 in the Washington Monthly poll of US universities meeting the 'Obama criteria' of access, diversity, affordability, and success probability.

12. Davis (1990) provides an unflinching view of the social and economic conditions that led to the 1992 uprising.

13. The other student became the first African-American to be named valedictorian for a graduating class at UCR. Despite receiving high marks in doctoral courses in microeconomics while completing her undergraduate degree, she entered a teachers-education program, and now teaches in an elementary school in Atlanta. 
14. Note that in the US system, students enter universities without declared majors, and instead sample courses across a range of disciplines before choosing a major in their second year of study.

15. One of these students, Zack Elder, participated in the subsequent MPP summer program and went on to earn his doctorate in economics. He now lives and teaches in Asia.

16. Guest lectures were given by Michael Stoll of UCLA and by Jessica Gordon Nembhard of the City University of New York.

17. This institutionalization was spearheaded by Teresa Cofield of the Learning Center. Ms Cofield, entered the doctoral economics program at Pennsylvania State University after graduating from UCR in 1993 with a double major in economics and mathematics. After one year, she returned to Southern California, subsequently earning an EDD degree.

\section{Disclosure statement}

No potential conflict of interest was reported by the author.

\section{References}

Agha, Marisa. 2004. "Celebration: The University is Marking its 50th Anniversary with a Variety of Events." Riverside Press-Enterprise, January 19.

Ambrose, Brent W., Charles A. Capone, Jr., and Yongheng Deng. 2001. "Optimal Put Exercise: An Empirical Examination of Conditions for Mortgage Foreclosure." The Journal of Real Estate Finance and Economics 23 (2): 213-234.

Ball, Stephen J., Diane Reay, and Miriam David. 2002. “Ethnic Choosing': Minority Ethnic Students, Social Class and Higher Education Choice." Race Ethnicity and Education 5 (4): 333-357.

Betsey, Charles L. 2008. "A Brief Biography of Robert S. Browne." The Review of Black Political Economy 35: 57-60.

Bracco, Kathy Reeves, and Patrick M. Callan. 2002. "Competition and Collaboration in California Higher Education.” Report No. 02-1. San Jose, CA: National Center for Public Policy and Higher Education.

California Citizens Commission on Higher Education. 1999. Toward a State of Learning: California Higher Education for the Twenty-first Century. Los Angeles, CA: Center for Governmental Studies.

Calomiris, Charles W., and Stephen H. Haber. 2015. Fragile by Design: The Political Origins of Banking Crises and Scarce Credit. Princeton, NJ: Princeton University Press.

Calomiris, Charles W., Charles M. Kahn, and Stanley D. Longhofer. 1994. "Housing-finance Intervention and Private Incentives: Helping Minorities and the Poor." Journal of Money, Credit and Banking 26 (3), Part 2: 634-674.

Collins, Susan M. 2000. "Minority Groups in the Economics Profession." Journal of Economic Perspectives 14 (2): 133-148.

Conrad, Cecilia A., and Rhonda V. Sharpe. 1996. “The Impact of the California Civil Rights Initiative (CCRI) on University and Professional School Admissions and the Implications for California Economy." The Review of Black Political Economy 25 (1): 13-59.

Crotty, James R., and Leonard A. Rapping. 1975. “The 1975 Report of the President's Council of Economic Advisors: A Radical Critique." American Economic Review 65 (5): 791-811.

Davis, Mike. 1990. City of Quartz. London: Verso.

Douglass, John Aubrey. 1999. "The Evolution of a Social Contract: The University of California before and in the Aftermath of Affirmative Action." European Journal of Education 34 (4): 393-412.

Dymski, Gary A. 1995. "The Theory of Bank Redlining and Discrimination: An Exploration." The Review of Black Political Economy 23 (3): 37-74.

Dymski, Gary A. 2014. “The Neoclassical Sink and the Heterodox Spiral: Political Divides and Lines of Communication in Economics.” Review of Keynesian Economics 2 (1): 1-19.

Evans, Brent A., Paul W. Grimes, and William E. Becker. 2012. "What Led Eminent Economists to Become Economists?” The Journal of Economic Education 43 (1): 83-98. 
Gerardi, Kristopher S., Andreas Lehnert, Shane M. Sherland, and Paul S. Willen. 2008. "Making Sense of the Subprime Crisis." Brookings Papers on Economic Activity Fall: 69-145.

Glyn, Andrew, Alan Hughes, Alain Lipietz, and Ajit Singh. 1990. "The Rise and Fall of the Golden Age." In The Golden Age of Capitalism: Reinterpreting the Postwar Experience, edited by Stephen Marglin and Juliet Schor, 39-125. Oxford: Clarendon Press.

Harcourt, Geoffrey C. 1969. "Some Cambridge Controversies in the Theory of Capital." Journal of Economic Literature 7 (2): 369-405.

Harrison, Bennett. 1972. "Education and Underemployment in the Urban Ghetto." American Economic Review 62 (5): 796-812.

Harrison, Bennett. 1974a. "Ghetto Economic Development: A Survey." Journal of Economic Literature 12 (1): $1-37$.

Harrison, Bennett. 1974b. "Ghetto Employment and the Model Cities Program." Journal of Political Economy 82 (2), Part 1: 353-371.

Horne, Gerald. 1995. The Fire this Time: The Watts Uprising and the 1960s. Charlottesville, VA: University of Virginia Press.

HoSang, Daniel Martinez. 2010. Racial Propositions: Ballot Initiatives and the Making of Postwar California. Berkeley: University of California Press.

Karabel, Jerome. 1999. "The Rise and Fall of Affirmative Action at the University of California." The Journal of Blacks in Higher Education 25: 109-112.

Kirst, David. 2007. The Evolution of California's State School Finance System and Implications from Other States. Stanford, CA: Institute for Research on Education Policy and Practice, Stanford University.

Leonardo, Zeus. 2007. "The War on Schools: NCLB, Nation Creation and the Educational Construction of Whiteness." Race Ethnicity and Education 10 (3): 261-278.

Li, Wei. 2008. Ethnoburb: The New Ethnic Community in Urban America. Honolulu: University of Hawaii Press.

McWilliams, Carey. 1946. Southern California: An Island on the Land. Layton, UT: Gibbs Smith. McWilliams, Cary. 1949. California: The Great Exception. Berkeley: University of California Press.

Michael, Jay, and Dan Walters. 2002. The Third House: Lobbyists, Money, and Power in Sacramento. Berkeley: Public Policy Press.

Moran, Rachel F. 2000. "Diversity and its Discontents: The End of Affirmative Action at Boalt Hall." California Law Review 88 (6): 2241-2352.

Munnell, Alicia H., Geoffrey M. B. Tootell, Lynn E. Browne, and James McEneaney. 1996. "Mortgage Lending in Boston: Interpreting the HMDA Data." American Economic Review 86: 25-53.

Musgrove, George Derek. 1999. "Good at the Game of Tricknology: Proposition 209 and the Struggle for the Historical Memory of the Civil Rights Movement." Souls 1 (3): 7-24.

Nicol, Donna J. 2013. "Movement Conservatism and the Attack on Ethnic Studies." Race Ethnicity and Education 16 (5): 653-672.

Rarick, Ethan. 2005. California Rising: The Life and times of Pat Brown. Berkeley: University of California Press.

Solórzano, Daniel G., and Tara J. Yosso. 2002. "A Critical Race Counterstory of Race, Racism, and Affirmative Action." Equity \& Excellence in Education 35 (2): 155-168.

Stock, Wendy A., and John J. Siegfried. 2015. "The Undergraduate Origins of PhD Economists Revisited." The Journal of Economic Education 46 (2): 150-165.

Taylor, Ula. 1999. "Proposition 209 and the Affirmative Action Debate on the University of California Campuses." Feminist Studies 25 (1): 95-103. 